\title{
The Augmented Meta-Public Space. Interpreting emerging transductive territories in enhanced centres of consumption
}

\author{
Manfredo Manfredini \\ The University of Auckland, New Zealand \\ School of Architecture and Planning \\ m.manfredini@auckland.ac.nz
}

\begin{abstract}
Recent socioeconomic and technological advancements are transforming the routines of consumption into post-consumerist practices. From a socio-spatial perspective, this is primarily driven by the augmentation of two main processes: prosumption and transduction. Addressing the condition of public space in rapidly developing cities in East Asia and Australasia, this paper discusses how these two forces have contributed to a novel spatial dimension: meta-publicness. The discussion is theoretically framed by two main streams of the research on public space: the one that approaches it as the irreducible realm of agonistic pluralism and the one which sees it as crucial to sociospatial ontogenetic processes. The major recent concept adopted in the new civic mall planning and management, experientiality, is discussed considering two main aspects: the role of eventful spectacularised environments in these hyper-mediated depoliticised spaces, and the re-politicising agency of their hyper-mediated connectedness. This paper concludes that if a democratisation of the spectacle has introduced relevant antagonistic decommodification forces, there is an internal weakness of the system that exposes these places to an even higher hegemonic dominance.
\end{abstract}

Keywords: public space, meta-public space, spatial transduction, presumption, shopping malls.

To cite this article:

Manfredini, M. (2017). The Augmented Meta-Public Space. Interpreting emerging transductive territories in enhanced centres of consumption. The Journal of Public Space, 2(3), Special Issue, I I -I28, DOI: I0.5204/jps.v2i3.I20

This article has been peer-reviewed and accepted for publication in The Journal of Public Space. Please see the Editorial Policies under the 'About' section of the journal website for further information.

This work is licensed under a Creative Commons Attribution - Non Commercial 4.0 International License https://creativecommons.org/licenses/by-nc/4.0/ 
66 We share a vision of cities for all, referring to the equal use and enjoyment of cities and human settlements, seeking to promote inclusivity and ensure that all inhabitants, of present and future generations, without discrimination of any kind, are able to inhabit and produce just, safe, healthy, accessible, affordable, resilient and sustainable cities and human settlements to foster prosperity and quality of life for all.

United Nations'

\section{The meta-public space and the metamorphosis of the mall: from hybrid consumption to advanced transductive prosumption.}

In modern cities, transformations of spatial patterns, technology and lifestyle have brought about a rapid evolution of the social role of enclosures of shopping and entertainment. From being spaces of pure consumption, the malls became spaces of hybrid ${ }^{2}$ and relational ${ }^{3}$ consumption, and, eventually, morphed into places of postconsumption. ${ }^{4}$ The latest transformation is particularly important as it has posed a serious challenge to consumption as the fundamental propelling force of these discrete urban elements. Post-consumerist practices emerge as malls tightly integrate the multiple realms of everyday life in dynamic assemblages of shopping, entertainment, work, culture and relational life, where non-retail operations are substantively expanded, urban amenities comprehensively incorporated and elements of civic identity abundantly added.

Although this evolution of malls has had a global character, its manifestation in certain social, cultural and geographical contexts has shown important differences. In East and Southeast Asia (particularly China and Indonesia) and Australasia (Australia and New Zealand), in cities that have developed rapidly, framing what has been dubbed post-civil ${ }^{5}$ society, these transformations have catalysed the formation of a peculiar variation of

\footnotetext{
' United Nations, "New Urban Agenda: Quito declaration on sustainable cities and human settlements for all," in United Nations Conference on Housing and Sustainable Urban Development, Habitat III Quito, Ecuador, October 2016, 2.

${ }^{2}$ Alan Bryman, The Disneyization of Society (London: Sage, 2004), 57-78; Simon Beames and Peter Varley, "Eat, Play, Shop: The Disneyization of Adventure," in Adventure Tourism: Meanings, Experience and Learning, ed. Steve Taylor, Peter Varley, and Tony Johnston (London: Routledge, 2013), 77-84; Jeffrey S. P. Hopkins, "West Edmonton Mall as a Centre for Social Interaction," The Canadian Geographer 35, n. 3 (199I): 268-279; Rob Shield "Spaces for the Subject of Consumption," Lifestyle Shopping: The Subject of Consumption (London: Routledge, 1992), I-20.

${ }^{3}$ Jonathan Murdoch, Post-Structuralist Geography (London: Sage, 2006); John Allen, "A More than Relational Geography?," Dialogues in Human Geography 2, n. 2 (2012): 190-193; Shaked Gilboa and Iris Vilnai-Yavetz, "Shop Until you Drop? An Exploratory Analysis of Mall Experiences," European Journal of Marketing 47, n. I2 (2013): 239-259; Johan Hagberg and Alexander Styhre, "The Production of Social Space: Shopping Malls as Relational and Transductive Spaces," Journal of Engineering, Design and Technology II, n. 3 (2013): 354-374. ${ }^{4}$ Halina Brown, Maurie Cohen, and Philip Vergragt, eds., Social Change and the Coming of Post-consumer Society: Theoretical Advances and Policy Implications (London: Routledge, 2017).

${ }_{5}^{5}$ Michiel Dehaene and Lieven De Cauter, "Heterotopia in a Postcivil Society," Heterotopia and the City: Public Space in a Postcivil Society, ed. Michiel Dehaene and Lieven De Cauter (Abingdon, Oxon: Routledge, 2008), 39; Rodrigo Satcedo, "When the Global Meets the Local at the Mall," American Behavioral Scientist 46, n. 8 (2003): 1084-I 103; Mark Gottdiener, The Social Production of Urban Space (Austin: University of Texas Press, 1985): 248-249; Lynn Staeheli and Don Mitchell, "USA's Destiny? Regulating Space and Creating Community in American Shopping Malls," Urban Studies 43, n. 5/6 (2006): 977-992.
} 
the newest paradigm: the civic megamall. ${ }^{6}$ This variation has emerged as a response to a highly dynamic urbanism made by multi-scalar networks of agglomerations, semirandom juxtapositions and exacerbated segmentations. ${ }^{7}$ The new malls have contributed to the unprecedented process of fragmentation of urban structures, social relations and everyday practices of local communities, supporting the progressive erosion of public space and the unrelenting privatization of the urban landscape. The entirely private spaces of these civic malls have reframed the public condition of sociospatial relationality of large portion of the population living in their trade areas. They have become primary nodes of social interaction in the highly dislocating urban environments of decentred post-utopian cities. ${ }^{8}$ Within the public sphere, they have assumed a compensatory networking agency that enables new forms of collective territorialisation.

These new civic elements provide spatial anchoring for otherwise despatialised interaction and have given rise to a novel dimension of publicness that we identify as meta-publicness. Our definition of a domain as meta-public applies to instances of coextension of public and private spheres that elude the binarism of the traditional classification of the publicness of spatial realms. More precisely, meta-public domains result from the loosening of boundaries in the quasi-public spaces of the preceding mall types, and the institution of hybrid, ambiguous and ambivalent territories, where public/private thresholds - though still heavily policed by hegemonic actors - lose part of their power to limit public access and engagement.

Intending to contribute to the discussion on the socio-spatial effects of the new condition of publicness, this paper elaborates upon the tenet that the profound changes in routines and actions in daily urban relational life are associated with the augmentation of two processes: prosumption and transduction. These are socio-spatial processes that have recently become nodal in the discourse on consumption. The prosumption process ${ }^{9}$ is a participative instance of transformational engagement. It concerns an intimate intertwining of consumption and production processes that, as posited by George Ritzer, always interpenetrate and no longer appear "as either pure production (without at least some consumption) or pure consumption (without at

\footnotetext{
${ }^{6}$ Manfredo Manfredini, Tian Xin, and Ross Jenner, "Transductive urbanism: A method for the analysis of the relational infrastructure of malled metropolitan centres in Auckland, New Zealand," Athens Journal of Architecture, 3, n. 4 (2017): 4 I I-440, available at: https:/www.athensjournals.gr/aja; Manfredo Manfredini, and Ross Jenner, "The Virtual Public Thing: De-re-territorialisations of public space through shopping in Auckland's urban space," Interstices: Journal of Architecture and Related Arts, 16 (2015): 70-8I.

${ }^{7}$ Peter Herrle, Josefine Fokdal, and Detlev Ipsen, Beyond Urbanism: Urban (izing) Villages and the Mega-Urban Landscape in the Pearl River Delta in China (Zürich: Lit, 20I4); Richard Sennett, "The Open City,” Urban Age (Berlin, 2006), available at http://www.urban-age.net; Michael Dear and Steven Flusty, "Postmodern Urbanism," Annals of the Association of American Geographers 88, n. I (I998): 50-72; Soja, Edward. "Regional Urbanization and the End of the Metropolis Era," in The New Blackwell Companion to the City, ed. Gary Bridge and Sophie Watson (Malden, MA and Oxford: Wiley-Blackwell, 20I I), 679-689.

${ }^{8}$ Fredric Jameson, Postmodernism, or the Cultural Logic of Late Capitalism (London: Verso, 1990); Mark Featherstone, Planet Utopia: Utopia, Dystopia, Globalisation (London: Routledge, 2017); Neville Mars, and Adrian Hornsby, The Chinese Dream: A Society under Construction (Rotterdam: 010 Publishers, 2008).

${ }^{9}$ George Ritzer and Nathan Jurgenson, "Production, Consumption, Prosumption: The Nature of Capitalism in the Age of the Digital 'Prosumer,," Journal of Consumer Culture 10, n. I (2010): 13-36; George Ritzer, "Prosumer Capitalism," The Sociological Quarterly 56 (20I5): 4I3-445.
} 
least some production)." ${ }^{10}$ It empowers people by giving them some control over what they consume, involving them in multiple nuances of consumerist and productive processes." For the strong impulse received by digital technology, prosumption emerges in advanced forms in the technologically enhanced meta-public realms. The spatial transduction process ${ }^{12}$ is an experiential instance of switching between alternative realms with different contextual references. It has the capacity to bring across realms of ambiguous and ambivalent double forms of real, semi-real and hyperreal (e.g. with forms of theming that stage local culture). Transductive instances are not permanent but temporal and based on dynamic, reiterative and transformative mechanisms. Their activation relies on multifarious technologies that produce sensorial and cognitive effects, combining analogue (e.g., themed material decoration) and digital (e.g., immersive virtual reality) means. For the power given by digital tools to these conversion mechanisms, the hyper-mediated atmospheres of the meta-public realms catalyses spatial transduction processes, continuously producing heterotopic spatialities that, as Bruno Latour described in his Invisible City, incarnate the dispersed plasma of hard urban reality and electronic utopias. ${ }^{13}$

The prosumption and transduction processes have found in the meta-public mall environments an ideal laboratory for combinatory experimentations and have contributed to the profound transformation of their physical and social infrastructures as well as their semantic representational constructs. The most obvious of these transformations is typo-morphological: the monolithic, large, closed, urban element that distinguished the architecture of the modern mall in its earlier stage has increased its size and fragmentation, to assume the complex form of a discrete part of the city its central core. Its utmost transduction is, indeed, the production of a pseudourbanity $^{14}$ that at the same time emulates and displaces the centre. It is a pseudourbanity of an implanted core that, while acting independently from the city, operates as a prosthetic organ of the urban body. The way it reproduces the functions and actions of traditional city cores is by mirroring its form, structure, operations, image and meaning. With regard to its urban structure, this core is organised as a hierarchical assemblage of composed heterogeneity, with a primary infrastructure reduplicating idealised networks of plazas, streets and lanes. It is a structure of optimised capillarity connecting homogeneous functional precincts and anchored on primary nodes, such as department stores, which take the place of civic institutions, such as theatres.

Functionally, this core has an all-encompassing programme that virtually include all the activities of the service sector: from retail to hospitality, from financial to personal

\footnotetext{
${ }^{10}$ George Ritzer, "Prosumption: Evolution, Revolution, or Eternal Return of the Same?" Journal of Consumer Culture, I4, n. I (2013): 10.

" Ritzer and Jurgenson, "Production, Consumption, Prosumption," I3-36; Ritzer, "Prosumer Capitalism," 4I3-445.

12 Hagberg and Styhre, "The Production of Social Space," 354-374; Rob Kitchin and Martin Dodge, Code/Space: Software and Everyday Life (Cambridge, MA: MIT Press, 20I I).

${ }^{13}$ Bruno Latour and Emilie Hermant, Paris Ville Invisible (Paris: La Découverte-Les Empêcheurs de Penser en Rond, 1998).

${ }^{14}$ Nicholas Jewell, "Eastern Promises," in The Shopping Centre, 1943-20 I3: The Rise and Demise of a Ubiquitous Collective Architecture, ed. Janina Gosseye and Tom Avermaete (Delft, The Netherlands: Delft University of Technology, 2015), 15-29.
} 
services, from information technology to education and health. Genuine public institutions, such as libraries and citizens advice bureaus, are also integral part of its prosumerist offering. Semantically, the narrative construct is consistently expressed throughout all morphological, material, decorative and naming levels. Particularly indicative of the latter, is the frequent designation of its central places as civic plazas, town centre squares and streets (Figure I and 2).

A peculiar type of introverted pattern distinguishes spatially the new self-reliant, independent urban organ: the ambivalent relationship between interior and exterior. ${ }^{15}$ The dual identification of clear inside and outside conditions, challenges one of the primary topological criteria of the urban structure it intends to mirror. Its key open "public" spaces epitomises this characteristic: the central plaza is an inside of an inside (the mall) and an outside of an outside (the civic public space proper) which is at the same time the space of highest indexicality and richness in contextual references, as well as the place of departure of the most internalised looping patterns and entrenched connectors. These juxtaposed landscapes produce transformative atmospheres of redoubling and repetition of the different, continuously reorganising their spatialities. To describe this wavering topology we can use a comment by Gilles Deleuze on Foucault's work where he articulated a way of describing forces able to place the immanence (inside) as always other (outside): "the outside is not a fixed limit but a moving matter animated by peristaltic movements, folds and foldings that together make up an inside: they are not something other than the outside, but precisely the inside of the outside". ${ }^{16}$

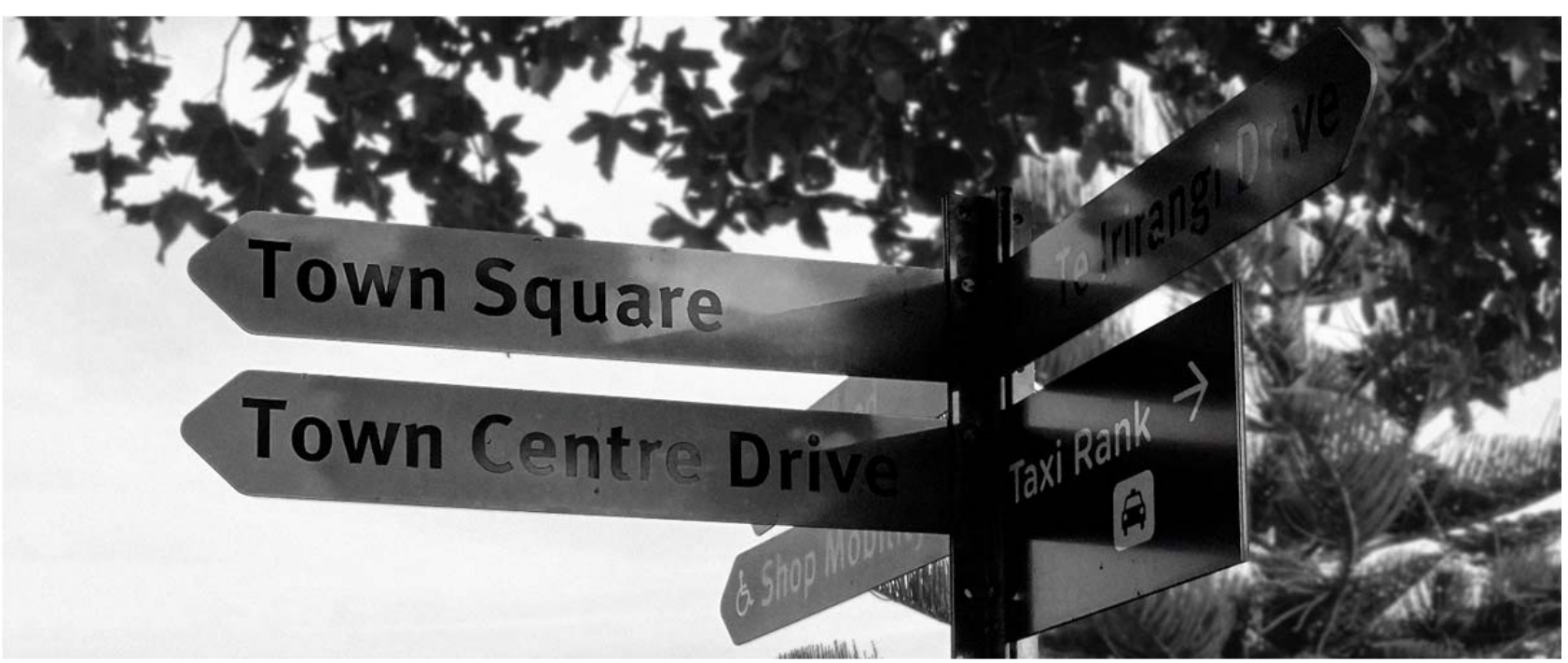

Figure I. Directional street sign in Botany Town Centre, one of the "civic malls" of Auckland, New Zealand. (C) Manfredo Manfredini, 2015.

\footnotetext{
${ }^{15}$ Fredric Jameson and Michael Speaks, "Envelopes and Enclaves: The Space of Post-Civil Society," Assemblage, n. 17 (1990): 35.

${ }^{16}$ Gilles Deleuze, Foucault (London: Continuum, 1999), 80.
} 
The ambivalence also destabilises the simple spatial inversion that characterised the previous mall types. In the new malls there is no place for the "reversed worlds" that Kim Dovey described as places where the combination of syntactic and semantic inversions instituted a threshold shifting the rules of the game, transforming the functional shopping into gratifying lifestyle, and permanently suspending it in hyperreality. ${ }^{17}$ In the new mall, the boundaries of these spaces continuously reverse and invert the quality of the territories they separate, making their interiors and exteriors coextensive, superimposing the homogenised, distanced and imagined realities of isotopia, heterotopia, and utopia. ${ }^{18}$

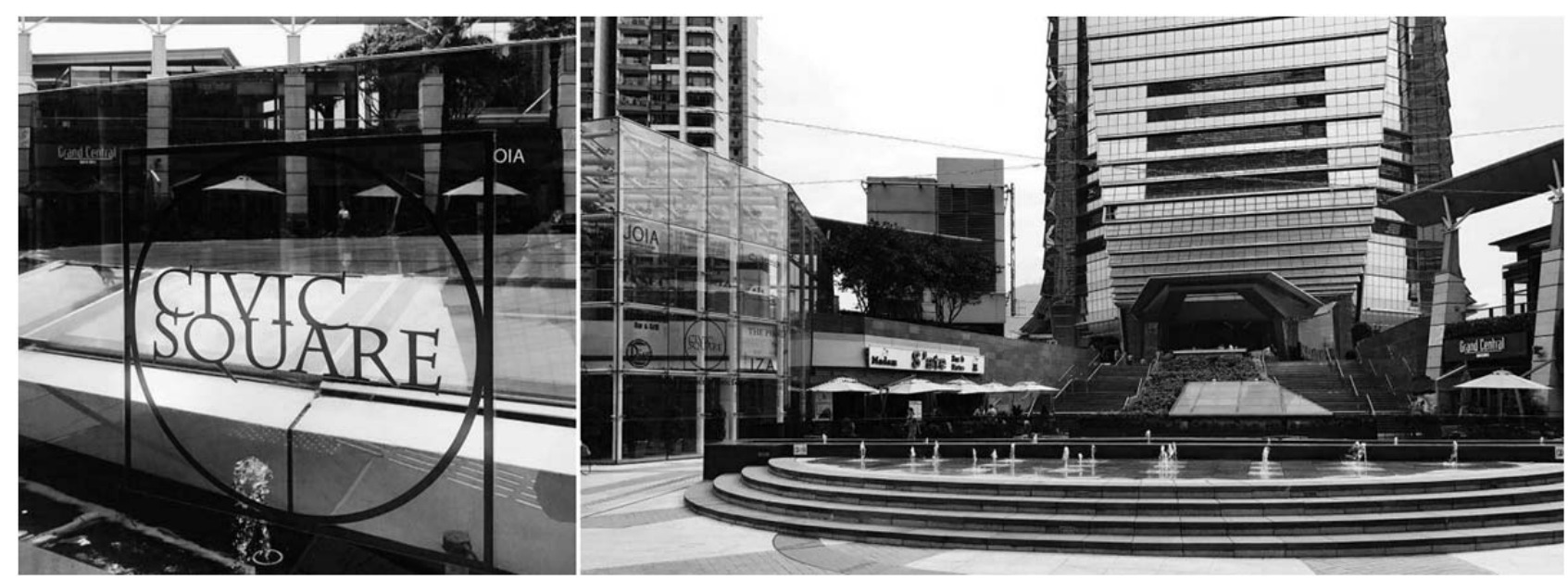

Figure 2. Civic Square signage and fountain on the third floor of the Union Square megablock (>I million square metres of floor space) in Kowloon, Hong Kong. (c) Luo Wen, 2017.

\section{Framing the socio-spatial condition of meta-public space}

Since the appearance of modern shopping centres, the relationship between conception (planning, implementation and management) and experience (perception and everyday life routines and actions) has been central to the urban discourse. Particularly relevant, in the literature on the recent development of cities, is the growing standing of spaces of consumption in social, spatial, cultural and legal fields. ${ }^{19}$

\footnotetext{
${ }^{17}$ Kim Dovey, Framing Places: Mediating Power in Built Form (New York: Routledge, 1999), I23-I 38.

${ }^{18}$ Henri Lefebvre, The Production of Space (Oxford: Blackwell, 1991), 163-164.

${ }_{19}$ Daniel Moeckli, Exclusion from Public Space: A Comparative Constitutional Analysis (Cambridge: Cambridge University Press, 2016); Steven Miles, Spaces for Consumption: Pleasure and Placelessness in the Post-Industrial City (Los Angeles: Sage, 2010); Mattias Kärrholm, Retailising Space: Architecture, Retail and the Territorialisation of Public Space (Farnham, Surrey: Ashgate, 2012); Stephen Carr, Public Space (Cambridge: Cambridge University Press, 1992); Sorkin Michael, ed., Variations on a Theme Park: The New American City and the End of Public Space (New York: Hill and Wang, 1992); Pauline Maclaran and Stephen Brown, "The Center Cannot Hold: Consuming the Utopian Marketplace," lournal of Consumer Research 32, n. 2 (2005): 3I I-323; Don Mitchell, "The End of Public Space? People's Park, Definitions of the Public, and Democracy," Annals of the Association of American Geographers 85, n. I (1995): I08- I33; Andrew Newman, Charles Dennis, and Shahid Zaman, "Marketing Images and Consumers' Experiences in Selling Environments," Marketing Management Journal I7, n. I (2006): I36-I50; Richard Sennett, "Reflections on the Public Realm," in A Companion to the City, ed. Gary Bridge and Sophie Watson (Chichester: Wiley-Blackwell, 2008), 380-387.
} 
The latest evolution of the malls discussed in this paper has importantly contributed to this expansion since it has exacerbated some of the main criticalities of the previous types: the segmentation of public space and the polarisation of social infrastructure in fragmented locales either produced through tabula rasa urban renewal processes or unrelenting growths of unbounded fabrics of disjointed domesticities. ${ }^{20}$ Many of these studies have focused on the effects on public life and everyday practices of the local communities of these private environments with conflated and polarised urban amenities. ${ }^{21}$ Links between privatisation and commercialisation of public space and homogenising mechanisms of social control and securitisation of these places have been examined and described. Their relation to increasing socio-spatial fragmentation of the contemporary urban society and problems affecting the wellbeing of citizens and communities, limiting inclusion, pluralism, civic engagement and relational life have been foregrounded. ${ }^{22}$ The tension between trends of progressive sharing, or transferring, of the control of urban space with leading actors of the market economy and the everlasting effort of the civil society to reconstitute the city as a commons and integrate collaborative social ecosystem faces has been widely discussed. ${ }^{23}$ The critical relevance of these issues in hindering communicative actions, encounter and dialogue for social development in our progressively diverse society has also been identified by the United Nations with the recent adoption of the New Urban Agenda. ${ }^{24}$ The substantive body of studies on the transformation of public space in urban environments dominated by modern enclosures has provided conspicuous theoretical and empirical instruments for evaluating the various aspects of their socio-spatial agency. The recent transformations that have led to what is identified here as a

\footnotetext{
${ }^{20}$ Thomas Campanella, The concrete dragon: China's urban revolution and what it means for the world (New York: Princeton Architectural Press, 2012); Chuihua Chung et al., eds., The Harvard Design School Guide to Shopping, Project on the City 2 (Cologne: Taschen, 200I); Peter Bloch, Nancy Ridgway, and Scott Dawson, "The Shopping Mall as Consumer Habitat," Journal of Retailing 70, n. I (1994): 23-42; Lizabeth Cohen, A Consumers' Republic: The Politics of Mass Consumption in Postwar America (New York: Knopf, 2003); Kimberley O'Sullivan and Manfredo Manfredini, "Sub-standard Housing and Access to Adequate Housing," in A State of New Zealand Report for UN Habitat III, ed. Dory Reeves, Stephen Knight Lenihan and Sandeeka Mannakkara (Auckland: The University of Auckland, 2016), 85-88.

21 Margaret Crawford, "The World in a Shopping Mall," Variations on a Theme Park: 3-30; Jon Goss, "The "Magic of the Mall": An Analysis of Form, Function, and Meaning in the Contemporary Retail Built Environment," Annals of the Association of American Geographers 83, n. I (1993): 18-47.

${ }^{22}$ Setha Low and Neil Smith, The Politics of Public Space (New York: Routledge, 2006); Adam Crawford, ed., "From the Shopping Mall to the Street Corner: Dynamics of Exclusion in the Governance of Public Space," International and Comparative Criminal Justice and Urban Governance (Cambridge: Cambridge University Press, 20II), 483-518;

Margaret Kohn, Brave New Neighborhoods: The Privatization of Public Space (New York: Routledge, 2004). Hugh Matthews, Mark Taylor, Barry Percy-Smith, and Limb Melanie, "The Unacceptable 'Flaneur': The Shopping Mall as a Teenage Hangout," Childhood 7, n. 3 (2000): 279-294; Anna Minton, "Ground Control," Arena Magazine (Fitzroy, Vic) II 9, Aug/Sept (2012): 34-37. Hopkins, "West Edmonton Mall," 268-279; Malcolm Voyce, "Shopping Malls in Australia: The end of Public Space and the Rise of Consumerist Citizenship?," lournal of Sociology 42, n. 3 (2006): 269-286; Sharon Zukin, "Urban Lifestyles: Diversity and Standardisation in Spaces of Consumption," Urban Studies 35, n. 5-6 (1998): 825-839.

${ }^{23}$ David Harvey, "From Managerialism to Entrepreneurialism: The Transformation in Urban Governance in Late Capitalism," Geografiska Annaler: Series B, Human Geography 7I (1989): 3-17; Stuart Hodkinson, "The New Urban Enclosures," City 6 (2012): 500-5I8.

${ }^{24}$ United Nations, "New Urban Agenda."
} 
condition of meta-publicness have, however, been only partially addressed in the field of urbanism. Studies on the spatial contribution that involves the re-politicisation of people's actions in spaces dominated by the processes framed here as transduction and prosumption, are particularly scarce and fragmentarily cover the socio-spatial problems. ${ }^{25}$ Two main aspects of a major recent concept, experientiality, adopted in mall planning and management, will be developed here at some length. First, the role of eventful spectacularised environments in these hyper-mediated depoliticised spaces. Second, the re-politicising agency of the hyper-mediated connectedness of these spaces.

\section{I The interactive environmental eventfulness of the meta-public space: From consumer of commodity fairgrounds to prosumer of experiential kaleidoscopes.}

In the second part of the last century, shopping centres were the contexts in which the critique of contemporary problems in the relations between sociability and political spheres identified the highest crisis of public space. The problems of the decay of the public realm originally ascribed to the consumerist distribution factories ${ }^{26}$ that originated in the 19th century department store, ${ }^{27}$ have been recognised in their exacerbation in the major modern centres of shopping where the society of the spectacle ${ }^{28}$ had its main expression. There, highly innovative spatial experiments had de-differentiated the forms of consumption and inhibited the traditional forms of production and interaction of the individual in public space. These places resulted from an extreme rationalisation process to maximise efficiency, control, predictability and calculability of commercial operations while encouraging consumers' everyday spending behaviours with impressive fairground spectacles of commodities ${ }^{29}$ in hedonic atmospheres akin to holiday destinations. ${ }^{30}$

Today, fifty years after the publication of Guy Debord's seminal critique of the The Society of the Spectacle, the character of these spaces has shifted from the consumerist hedonic to the post-consumerist experiential. ${ }^{31}$ This has developed the fundamental ambivalence of prosumption into a force that, somewhat paradoxically, debilitates the consolidated substantive spectacular depoliticisation. In the last generation of malls, the very same forces that commercialised and made prime commodity of social, recreational and seductive values, ${ }^{32}$ strove actively to engage consumers in co-creative

\footnotetext{
${ }^{25}$ Janina Gosseye, Tom Avermaete, and Bruno De Meulder, eds., Acculturating the Shopping Centre (Abingdon, UK: Taylor and Francis, forthcoming); Rob Kitchin, and Martin Dodge, "Placing' Cyberspace: Geography, Community and Identity," Information Technology, Education and Society 16, n. I (20I5): 23-43; Hagberg and Styhre, "The Production of Social Space," 354-374.

${ }^{26}$ Guy Debord, The Society of the Spectacle (New York: Zone Books, 1994), 62.

${ }^{27}$ Richard Sennett, The Fall of Public Man (New York: Knopf, 1977).

${ }^{28}$ Debord, The Society of the Spectacle.

${ }^{29}$ Jean Baudrillard, The Consumer Society (London: Sage, 1998), 28.

${ }^{30}$ Bryman, The Disneyization of Society, 58.

${ }^{31}$ Joseph Alba and Elanor Williams, "Pleasure Principles: A Review of Research on Hedonic Consumption," Journal of Consumer Psychology 23, n. I (2013): 2-I8; Joseph Pine and James Gilmore, The Experience Economy (Boston: Harvard Business School Press, 1999).

${ }^{32}$ Shaked Gilboa, Iris Vilnai-Yavetz, and Jean Charles Chebat, "Capturing the Multiple Facets of Mall

Experience: Developing and Validating a Scale,” Journal of Consumer Behaviour I5, (2016): 48-59.
} 
and digitally supported dynamics that progressively democratised and combined the production and consumption of the spectacle.

To interpret how this ambivalence includes forms of re-politicisation of the individual, guidance can be found in the body of literature on the modern destabilisation of traditional processes in contemporary cities. These studies have focused on the transformation of the interaction between individuals and their environment, shedding light on the processes of identification and attribution of meanings and values to places through the combination of personal and collective conceived, perceived and lived practices. ${ }^{33}$ Their attention to relational actions and practices provides insights for the study of this entangled condition of malled space, offering conceptual instruments to interpret the evolution of the public-private relations, ${ }^{34}$ articulating aspects of form and experience from the perspective of the consumer.

The tradition of studies hinging on the seminal work of Hannah Arendt is particularly relevant, as it addresses problems of the private seizure of publicness and articulates them in the critique of the loss of "agonistic pluralism." 35 Her studies underline the relevance of socio-spatial conditions that support the complex formation of what she defines as collective worlds. These worlds are intended as permanent institutions - in her words a community of things - able to gather together and relate individuals in material space to substantiate and guarantee the development of culture and democratic systems. Arendt observes that their disappearance in modern society has led to the atrophy of political life. This is a process of occlusion of the political, where the pervasion of production and consumption logics blurs the distinction between the private and the public. She notes the transformation of public space into a pseudospace of interaction where individuals "no longer 'act' but 'merely behave' as economic producers, consumers and urban city dwellers." 36 The critique of the reduction of publicness to a sphere of passive cultural consumption was importantly expanded by Jürgen Habermas. Although from a different position, he argued that the power given to private actors - particularly the corporate ones - by modern audio-visual mass media supported their re-feudalisation of the modern public sphere. Entertainment and advertising replaced public discourse, obstructing practices of rational-critical discourse

\footnotetext{
${ }^{33}$ Michel de Certeau, The Practice of Everyday Life (University of California Press: Berkeley, 1984); Thomas Gieryn, “A Space for Place in Sociology,” Annual Review of Sociology 26 (200I): 493-496; Richard Stedman, “Is it Really Just a Social Construction? The Contribution of the Physical Environment to Sense of Place," Society \& Natural Resources An International Journal 16, n. 8 (2003): 67I-685; Yi-Fu Tuan, Space and Place: The Perspective of Experience (London: Edward Arnold, 1977); Richard Wohl and Anselm Strauss, "Symbolic Representation and the Urban Milieu," American Journal of Sociology 63, n. 5 (1958): 523-532; Henri Lefebvre, Rhythmanalysis: Space, Time and Everyday Life (New York: Continuum, 2004); Critique of Everyday Life II: Foundations for a Sociology of the Everyday (London: Verso, 2002).

${ }^{34}$ Jeff Weintraub and Krishan Kumar, Public and Private in Thought and Practice: Perspectives on a Grand Dichotomy (Chicago: University of Chicago Press, 1997).

${ }^{35}$ Hannah Arendt, The Human Condition (Chicago: University of Chicago Press, 1958); Lynn Staeheli and Don Mitchell, “USA's Destiny?”; Chantal Mouffe, "Public Space and Democratic Politics," Laps (2007): I- I0.

${ }^{36}$ Sheila Benhabib, "Models of Public Space: Hannah Arendt, the Liberal Tradition, and Jürgen Habermas," in Habermas and the Public Sphere, ed. Craig Calhoun (Cambridge, MA: MIT Press, 1992), 90; Arendt, The Human Condition.
} 
on political matters that substantiate participative and emancipative processes. ${ }^{37} \mathrm{His}$ concerns about the resulting alienation and splintering of common grounds are shared, yet severely criticised, by the "agonistic" scholars who have taken a stand for a radical multiplicity and heterogeneous coexistence to produce complex blending of diversity. Observing the striated imperfection of globalisation and acknowledging the irreducibility of conflicts where "parties recognize the legitimacy of their opponents," they have claimed the fundamental role of space for the constitution ${ }^{38}$ of pluralistic and networked realms, free from the control of dominant powers.

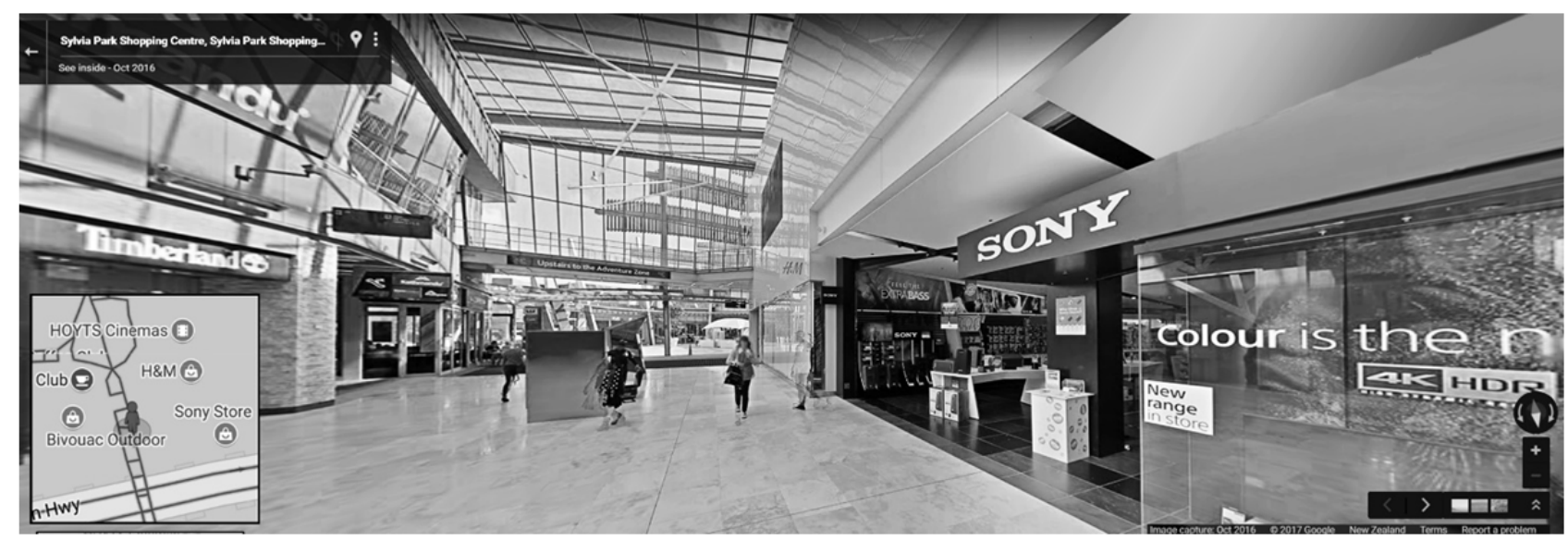

Figure 3. Panoramic "street view" of the interior of the main concourse of Sylvia Park, Auckland, the largest shopping mall in New Zealand. () 2017 Google.

\subsection{Experiential spaces and hyper-mediated environments}

The strategies to augment the experiential quality of space ${ }^{39}$ include forms of eventful activation of space with synchronisation of embodied rhythms. These strategies reflect the emphasis on improving user experience that has recently penetrated and become an imperative in the agenda of all levels of spatial governance to amplify the attractiveness of places. Commercial environments, and more specifically malls, have been at the forefront of this trend. They have implemented these strategies with multiple tactics to produce ever different experiences with engaging, emotional,

\footnotetext{
${ }^{37}$ Craig Calhoun, "Introduction: Habermas and the Public Sphere," in Calhoun, Habermas and the Public Sphere; Jürgen Habermas, The Structural Transformation of the Public Sphere: An Inquiry into a Category of Bourgeois Society (Cambridge, MA: MIT Press, 1989); "Further Reflections on the Public Sphere," in Calhoun, Habermas and the Public Sphere; Jürgen Habermas and Thomas McCarthy, "Hannah Arendt's Communications Concept of Power," Social Research 44 (I 977): 3-24.

${ }^{38}$ Chantal Mouffe, The Democratic Paradox (London: Verso, 2000); Chantal Mouffe, "Space, Hegemony and Radical Critique," in Spatial Politics: Essays for Doreen Massey, ed. David Featherstone and Joe Painter (London: Wiley, 20I3), 22-3I.

39 Barry Babin, William Darden, and Mitch Griffin, "Work and/or Fun: Measuring Hedonic and Utilitarian Shopping Value," Journal of Consumer Research 20, n. 4 (1994): 644-656; Adam Lindgreen, loëlle Vanhamme, and Michael Beverland, eds., Memorable Customer Experiences: A Research Anthology (Farnham: Gower, 2009); Michael Jones, Kirsty Reynolds, and Mark Arnold, "Hedonic and Utilitarian Shopping Value: Investigating Differential Effects on Retail Outcomes," Journal of Business Research 59, n. 9 (2006): 974-98I; Joseph Pine II and James Gilmore, "Welcome to the Experience Economy," Harvard Business Review 76 (July 1998): 97-105.
} 
coherent and cognitively important features. They include both permanent and occasional events with unlimited diversification, including such things as pop-up shows, recurrent festivals, exotic sportainment and touring opportunities (e.g., indoor skydiving, ice skating, "immersive" aquarium strolling and balloon rides), which integrate mechanisms to induce and control behaviours, and coordinate emotional drivers, such as belonging, excitement and enjoyment, as well as bodily rhythms, such as those related to movement, fatigue and hunger.

The interpretation of the socio-spatial effects of the enhanced differentiation in these eventful systems is illuminated by the Lefebvrian critique of space as an ontogenetic and permanently integrated multidimensional realm. ${ }^{40}$ This approach to socio-spatial transitions is particularly useful to understand the progressively specialised and fragmented urban conditions. It focuses on the forces behind them, deploying a complex analysis to distinguish the different forces in their unbalanced power relations and unified play. The agency of dominating powers located outside the local sociospatial fields of their production of physical, cognitive and social space is critically studied and the logics that underlie the governance of complex apparatuses, where collective control is minimised, are revealed.

To explain the peculiar impact on perceptual, cognitive and enactive abilities of the users of these apparatuses, Henry Lefebvre articulated a multidimensional instrument distinguishing conceived, perceived and lived spatialised relations. This specifically disentangles the complex strategies deployed to produce spaces to be perceived as differential by controlling powers through specific historic and geographic processes. He defined these as abstract spaces, to underline the abstraction used by these powers to establish and perpetuate their hierarchical systems, thereby assigning special status to particular organisations and places, and at the same time stipulating various forms of exclusion. To implement abstraction, a particular law ${ }^{41}$ of homogenisation is adopted: the obliteration and flattening of differences that hinder external control. Yet, to function effectively, staged induced differentiation is abundantly used to compensate for the flaws of the diminished real.

The pseudo-urbanities are produced by dissimulative transduction processes that deliberately induce, as Lefebvre claimed, false consciousness. The pseudo-differential abstraction, with masked reduplications, functionalises symbols to activate the power of metaphor and myth to produce spectacles staging illusory full realms of plenitude. ${ }^{42}$ This has a quasi-magical power to instigate "marvellous self-deceptions" 43 that reduce the collective capacity to distinguish genuine references in the processes of

\footnotetext{
${ }^{40}$ Lefebvre, The Production of Space; The Urban Revolution (Minneapolis: University of Minnesota Press, 2003); Critique of Everyday Life I, (199I); Writings on Cities (Cambridge: Blackwell, 1996); Everyday Life in the Modern World (New Brunswick, NI: Transaction Books, 2003); David Harvey, "From Space to Place and Back Again: Reflections on the Condition of Post Modernity," in Mapping the Futures: Local Cultures, Global Change, ed. lon Bird et al. (London: Routledge, 1993), 3-29; Edward Soja, Thirdspace: lourneys to Los Angeles and Other Real-andImagined Places (Cambridge, MA: Blackwell, 1996); Postmodern Geographies: The Reassertion of Space in Critical Social Theory (London: Verso, 1989); Mark Purcell, "Excavating Lefebvre: The Right to the City and Its Urban Politics of the Inhabitant," Geojournal 58, n. 2 (2002), 99-10.

${ }^{41}$ Lefebvre, The Production of Space, 372.

${ }^{42}$ Lefebvre, The Production of Space, 28.

${ }^{43}$ Lefebvre, The Production of Space, 189.
} 
identification, distinction, naming, recognition, connection and ownership of places. This threatens traditional developments of collective forms of interpretation, elaboration and development of experiences of places that constitute identity and a sense of belonging, substantiating personal and communal biographies and narratives. ${ }^{44}$ Jon Goss has described these places as dreamhouses of the collectivity: repositories of cultural images of utopia that mirror a regime in which "the collective dream of authentic life is not expressed in the political process but is distorted by ideology and harnessed to commodity consumption." ${ }^{45}$ There, where the marvel hinges on perceived hyperspatial authenticity, multiple simulations transform the real into represented pseudo-utopias/heterotopias of compensation, such as in the private boudoirs or jewellery ambiences of certain chains of coffee shops. The marvel of this deception includes the social dimension, where virtual and augmented reality support personal relations, merging face-to-face and remote interaction in both synchronous, semi-synchronous and asynchronous ways.

Specific to the digital age is the augmentation that has made the mall-dreamhouses transformative, both in scale and quality, to cater for the different needs and desires of communities, groups and the individual. This is made possible through the creation of hyper-mediated environments that personalise their features and support, simultaneously, different forms of place-based relationality. Hyper-mediated environments create unprecedented spatial multiplicity. They are an augmented form of Foucauldian heterotopias of juxtaposition that simultaneously places "in a single real place several spaces [of] several emplacements that are in themselves incompatible. ${ }^{46}$ Their equipment, with enhanced and high-performance digital infrastructure and services (e.g., interactive physical interfaces and virtual shopping assistants), provides real-time spatial tuning that spans from micro to macro scale, from personal to collective, providing multiple accesses to spatialities that range from the simultaneous to the asynchronous and from augmented to the virtual. ${ }^{47}$ Unconditionally enabling creation and access from any time and place, these spaces irrupt into the traditional spatio-temporal flows, enabling everyday practices to engage with another particular form of Foucault's other places: the heterotopia of illusion. This is the place in which normalisation leaves space to its opposite: subversion, heterogeneity and excess. ${ }^{48}$ As hyper-mediated illusionary juxtaposing heterotopias, the civic malls have a particular role in the re-politicisation of the individual. With the implementation of multiple locative and augmented reality applications, they have become prime urban places for the embodiment of the digital sphere. This process of bringing back to place and

\footnotetext{
${ }^{44}$ Peter J. M. Nas, "The Urban Anthropologist as 'Flâneur': The Symbolic Pattern of Indonesian Cities," Wakana I4, n. 2 (2012): 429-454; Sharon Zukin, Naked City: The Death and Life of Authentic Urban Places (Oxford: Oxford University Press, 2009).

${ }^{45}$ Jon Goss, "Once-upon-a-Time in the Commodity World: An Unofficial Guide to Mall of America," Annals of the Association of American Geographers 89, n. I (1999): 45.

${ }^{46}$ Michel Foucault, "Of Other Spaces," in Dehaene and De Cauter, Heterotopia and the City, I3-29.

${ }^{47}$ Richard Coyne, The Tuning of Place: Sociable Spaces and Pervasive Digital Media (Cambridge, MA: MIT Press, 2010); Charles Soukup, "The Postmodern Ethnographic Flaneur and the Study of Hypermediated Everyday Life,” Journal of Contemporary Ethnography 42 (2012): 226-254. Exploring Screen Culture via Apple's Mobile Devices: Life Through the Looking Glass (Lanham: Lexington Books, 2016).

${ }^{48}$ Foucault, "Of Other Spaces," I3-29.
} 
rooting the space of flow ${ }^{49}$ has reinforced their civil ambivalence as central nodes: while the external organisations that own, manage and control these urban elements increase their predominance, the juxtaposition logic of this digitally augmented intensification of socio-spatial polarisation enables the simultaneous presence and centralisation of antagonist realms composed by autonomous individuals and grassroots organisations. These antagonist realms can include, given the illusionary logic, realms of subversion and heterogeneity ${ }^{50}$ that, in Lefebvrian terms, act in contention with the abstract, minimal and induced differentiation to establish a qualitative, productive and maximal difference.

Concerning the spatial hegemony of the commercial organisations of the malls, hypermediation increases their potential, stabilising and reinforcing their dominant position. The digital environment enables the widening of the traditional applied logics of anchoring that underlie the conception of these developments. The implemented capability expands the traditional applied strategies of communication with locative, omnichannel and multimedial digital means, which magnify the tactics based on branding, bricks and mortar theming, "cappuccino pacification" ${ }^{51}$ and son et lumière distraction. ${ }^{52}$ The holding power of the anchors has been expanded with enhanced marketing instruments to cope with the new prosumer-led market that is more and more pervaded by the online component (e.g., the ad hoc integrated on- and off-line solutions created by dedicated branches of marketing departments, research laboratories and think tanks, such as the recently created Westfield Retail Solution centre). This has enhanced their category-killer effect, since local competitors cannot afford to deploy the required resources.

The digital augmentation primacy of the malls includes an extra support to the Internet-of-Things, with mobile applications that enhance information flows, spatial intelligibility and accessibility, social interaction and gaming. The overabundant and continuously updated availability of information and data on proprietary and global media services elicits co-production of hybrid spatialities merging material and virtual contents. The array of locative and real-time mobile services with personalised interfaces and push notifications provides unconstrained visibility and accessibility of things. This includes applications that are dedicated-proprietary, such as the "discover more to love" Westfield Shopping AU, or hybrid, such as the new online-to-offline retail Meituan-Dianping (China's largest provider of on-demand services), or global, such as Forsquares and Google. The integrated system of services connecting multiple fixed physical interfaces, such as interactive monitors, with visitor's mobile devices enhances spatial perception, navigation and discovery. This includes, for example,

\footnotetext{
${ }^{49}$ Manuel Castells, "The Rise of the Network Society," The Information Age: Economy, Society and Culture I (Oxford: Blackwell, 1996).

${ }^{50}$ Manfredo Manfredini, and Anh-Dung Ta, Co-Creative Urbanism: The production of plural evolutionary spatialities through conflicts and complicities between public and private in the streets of Hanoi, Vietnam," Joelho, Journal of Architectural Culture, 7 (2016): I I0-I3 I; Manfredo Manfredini, and Farzad Zamani Gharaghooshi, "Instances of Emerging Agonistic Spatialities in the Contemporary City: The Production of Differential Geographies in the Public Space of Istanbul," in Contemporary Urban Issues, ed. Hande Tulum (Istanbul: Dakam Publishing), 50I-5I3.

51 Sharon Zukin, The Cultures of Cities (Oxford: Blackwell, 1995), 28.

${ }^{52}$ Crawford, "The World in a Shopping Mall," 3-30; Goss, "The 'Magic of the Mal'," I8-47.
} 
micro GPS navigation (e.g., Google Maps has full coverage of mall interiors, with Street View panoramas; Figure 3 amd 4a) and augmented reality discovery (e.g., World Around Me and, shortly, Google Lens show directions, distances and webpage links to nearby point of interests, such as shops, restaurants and public transport stops; Figure 4b). The heightened effectivity of social "radar" applications favours meeting or making new friends. This higher potential for new encounters in mall environments, through locative social search mobile applications, is generated by their very high network effects (elements such as perceived high safety of their highly policed spaces also contribute to it, as revealed by research on users of dating applications). The high concentration of networks and nodes of locative interactive games (e.g., the density of Gyms and Stops of Niantic's Pokémon Go AR application; Figure 4c) has malls as foremost sites of digital gaming in public space.

With regard to the antagonist realms of autonomous individuals and grassroots organisations that these digital augmentations have reactivated, the hyper-mediation has reintroduced their action in the production of multiple spatialities in the malls and, with it, brought into being a differential space. This is mainly due to the support given to prosumption practices that through digital embodiments have a place in the production of maximal difference, accessing domains that were previously exclusive to the external abstractive forces. These practices have a powerful agency to take back to the locale the control of some of the transduction processes responsible for the sociospatial deterritorialisation and reterritorialisation. They have rehabilitated collective processes of spatial ontogenesis that actively shape and appropriate places of free socio-spatial association. They have re-embodied realms otherwise present only in despatialised flows of the hyperspace.

The re-embedment of antagonist realms counters the condition of displacement typical of the older malls; a condition that, as Jameson pointed out, transcends "the capacities of the individual human body to locate itself, to organize its immediate surroundings perceptually, and cognitively to map its position in a mappable external world." ${ }^{23}$ This occurs because the spatial hybridity produced by the mobile digital pervasion ${ }^{54}$ opens the mall to forms of independent access through multiple channels and layers of communication of the augmented atmospheres. ${ }^{55}$ As a result, actors, scenes and operations of both the material and immaterial sphere are permanently mobilised, renetworked and re-established ${ }^{56}$ in a tension between abstractive and differential forces

\footnotetext{
${ }^{53}$ Fredric Jameson, Postmodernism, or, the Cultural Logic of Late Capitalism (Durham: Duke UP, I99I): 83.

${ }^{54}$ Adriana de Souza e Silva, "From Cyber to Hybrid: Mobile Technologies as Interfaces of Hybrid Spaces," Space and Culture 9, n. 3 (2006): 26I-278; Alan McKeon, “Using Social Media Insights to Drive Shopper Engagement at the Mall”, Retail Property Insights 2I, n. 2 (2015): I3-I4; lerry Kang and Dana Cuff, "Pervasive Computing: Embedding the Public Sphere," Washington and Lee Law Review, 62 (2005): 93-I46.

${ }^{55}$ Adriana de Souza e Silva and Jordan Frith, "Locative Mobile Social Networks: Mapping Communication and Location in Urban Spaces", Mobilities 5, n. 4 (2010): 485-505; Keith Hampton, "The Social Life of Wireless Urban Spaces: Internet Use, Social Networks, and the Public Realm," Journal of Communication 60, n. 4 (2010): 701-722.

${ }^{56}$ Kitchin and Martin, Code/space; Rob Kitchin and Sung-Yueh Perng, Code and the City (London: Routledge, 2016); Rob Kitchin and Martin Dodge, "Code and the Transduction of Space," Annals of the Association of American Geographers 95, n. I (2005): I62-180.
} 
growing within the system that used to deliver conditions silencing individuals and making them unable to adopt critical stances. ${ }^{57}$
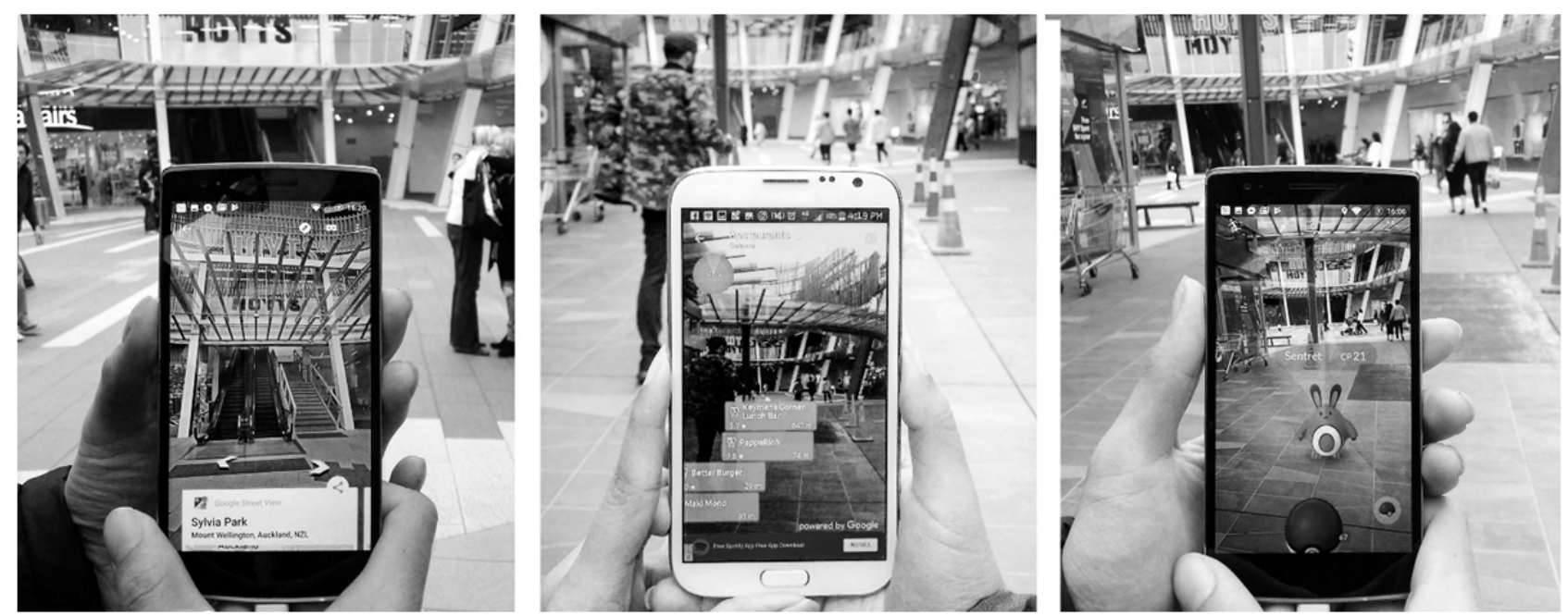

Figure 4. Augmented reality mobile applications for a) navigation (Google’s Google Map Street View ()),

b) discovery (WT InfoTech's World Around Me (C) and c) gaming (Niantic's Pokémon GO) in the Centre Court of Sylvia Park mall. (C) Angelo Bueno and Tanyalak Chalermtip, 2017.

\section{Towards ambiguous territorialities}

Interpreting the meta-publicness of the new civic megamall as a combination of the ambivalences in socioeconomic (augmented prosumption) and socio-spatial (augmented transduction) relations, the question of the effectiveness of its political agency arises. The core of the question is whether this condition has an impact on the quality of life for all, improving the limits of accessibility and inclusion that have characterised the pseudo-interaction of the quasi-publicness of the other mall types. A peculiar characteristic of meta-publicness is its openness and capacity to make permeable and productive the boundaries between the territories controlled by various actors. The openness of territories recombines the forms of their identification, appropriation and association, disempowering the dominating external forces and empowering the locale. In Lefebvrian terms, this new condition strengthens differential and distinctive forces over the abstractive and homogenising ones, making difference emerge. The difference, as continuous proliferation and transformation of territories, is granted by prosumerist-transductive augmentations that give form to modern heterotopias of juxtaposition and illusion. The difference emerges from effectively engaged people in multiple socio-spatially networked contexts ${ }^{58}$ supported by spatial embodiments of the digital public sphere through mediations and interconnections of material and virtual platforms and communication flows. The

\footnotetext{
${ }^{57}$ Lefebvre, The Production of Space, 287.

${ }^{58}$ Cynthia Susilo and Bruno De Meulder, "The Boulevard Commercial Project of Manado, Indonesia: Trickled-down Globalization Versus a Catalyzed Super Local,” in The Shopping Centre, 1943-2013: The Rise and Demise of a Ubiquitous Collective Architecture, ed. Janina Gosseye and Tom Avermaete (Delft: Delft University of Technology, 20I5), 4I-55.
} 
difference is framed in the continuous hybridisation across the entire spectrum of the social, cultural and spatial domains that, as Mubi Brighenti posited, ${ }^{59}$ produce complex territorialities made of fields in steady reproduction, unpredictable multiplication and interpenetration.

An example of this differentiation in these meta-public, transductory and prosumerist spaces is the blurring of information flows on digital social media. There, communication transitions seamlessly between areas controlled by the external dominating powers and the pluralistic networks of grassroots organisations and autonomous individuals. This phenomenon, which has undermined the one-way relationship of the flows between the dominating power and the isolated individuals, distinguishes the new meta-public space from the preceding quasi-public. It has strengthened participation and engagement in the public sphere, enabling autonomous individual expression through multimodal means, including media interlinking multiple platforms (e.g., between the public and private parts of a social networking service, such as Facebook, and/or photo-sharing application, such as Instagram, using reposting practices). This has enhanced participation and engagement in an unprecedented inclusionary process, granting access to the other, the marginalised and the "dangerous giants" ${ }^{60}$ that have "the capacity to disrupt and destroy the material and digital structures in which they find themselves."

Handheld devices, the prime and often the only access to the public sphere while in public spaces, epitomise this phenomenon. They can make un-private ${ }^{62}$ each individual's actual or archived act, idea and perception using multiple media and channels enabling the regulation of temporal (e.g., with real-time streaming), thematic (e.g., with advanced bookmarking and tagging) and authorial (e.g., with semi-anonymous identification) attributes in public communication. This de-privatisation is facilitated by the augmentation of spatialities of sheer consumption that - as described by Lefebvre ${ }^{63}$ - have acquired the power of mirror and mirage through the "logic of visualisation," immersing individuals in representations of the publicness that are at once true and false. The disappearance of the reality principle ${ }^{64}$ in contemporary "[obscene] ecstasy of communication" favours a reverse pervasion of the public into the private, with users enabled to claim public spaces in their private ones.

The transitional condition between opposing spatialities, though, is highly problematic and matches the one that Sharon Zukin defined as socially liminal: an ambiguous and ambivalent condition that complicates the constructions of spatial identity. ${ }^{65}$ The way it counters the abstractive forces within the existing geographies of power is subject to a

\footnotetext{
${ }^{59}$ Andrea Mubi Brighenti, “Mobilizing Territories, Territorializing Mobilities," Sociologica 8, n. I (20।4).

${ }^{60}$ Erving Goffman, Encounters (Indianapolis: Bobbs-Merrill, 196I).

${ }^{61}$ Ritzer, "Prosumer Capitalism", 4I3-445.

${ }^{62}$ William Mitchell, Me++: The Cyborg Self and the Networked City (Cambridge, MA: MIT Press, 2003).

${ }^{63}$ Lefebvre, The Production of Space, 189.

${ }^{64}$ Jean Baudrillard and Arthur B. Evans. "Simulacra and Science Fiction (Simulacres et science-fiction)", Science Fiction Studies (199I): 309-3 I3; Jean Baudrillard, The Ecstasy of Communication (New York: Semiotext(e), 1988).

${ }^{65}$ Sharon Zukin, Landscapes of Power: From Detroit to Disney World (Berkeley: University of California Press, 199I); Sharon Zukin, "Postmodern Urban Landscape: Mapping Culture and Power," in Modernity and Identity, ed. Scott Lash and Jonathan Friedman (Oxford: Blackwell, 1992), 22I-47.
} 
major threat posed by one of the key characteristics of its recombinant openness. This is the constitutive privateness of systems, both material and digital, that enables the impermanent, transformational dynamism of the new participative reterritorialising and reterritorialising processes. The risk that lacking public control on these new sociospatial relational systems undermines the potential of the meta-publicness in supporting diversity, equality and inclusion is immanent in them. New processes of seizure of publicness with surreptitious colonisation by the hegemonic private organisation are high. Other sectors of the framing "sharing economy" have already been deeply affected by disruptive effects of the pervasion of the private, as several studies show. ${ }^{66}$ This also concerns social isolation, since the compensatory effect of the new participative condition seems still very limited. ${ }^{67}$

An augmentation of the ambiguity between public and private character further articulates the exposure of each relational act to the monitoring and control of hegemonic external powers. While, in the digital public sphere, these risks are well known and have already led to important countermeasures, such as the restrictions of services (e.g., the recent ones regarding access to application programming interfaces of leading social media services, such as Sina Weibo and Instagram), little attention has been given to them in the augmented meta-public spaces. This is also caused by the legal status of the malls, where the complex legislative frameworks framing the public/private ambiguity of their spaces have been highly controversial and have led to protests and legal disputes, which, in a few cases, have even resulted in the statutory recognition of their publicness. ${ }^{68}$

Time will tell us whether the meta-publicness of democratised spectacle, whose traces have been found in the places of the most intense spatial, social and psychological transduction, will support the development of antagonistic decommodification forces and create spatialities of effective agonistic pluralism, or whether the intrinsic weaknesses of the systems that have supported it will permit the development of even more abstractive socio-spatial emplacements that stabilise the antagonist dominance of hegemonic actors with the hyper-spectacle of augmented and gamified ${ }^{69}$ fantasies of authentic life ${ }^{70}$

\footnotetext{
${ }^{66}$ Adriana de Souza e Silva, "Pokémon Go as an HRG: Mobility, Sociability, and Surveillance in Hybrid Spaces," Mobile Media \& Communication 5, n. I (2016): 20-23; Ritzer, "Prosumer Capitalism," 4I 3-445.

${ }^{67}$ John D. Boy and Justus Uitermark, "Reassembling the City Through Instagram," Transactions of the Institute of British Geographers, version of record online: 7 lune 2017, doi: I 0.1 I I /tran. 12 I85.

${ }^{68}$ Anna Minton, Ground Control: Fear and Happiness in the Twenty-first-Century City (London: Penguin, 2012); Kohn, Brave New Neighborhoods.

${ }^{69}$ Eric J. Arnould, Linda L. Price, and Patrick Tierney, "Communicative Staging of the Wilderness Servicescape," Service Industries Journal 8, n. 3 (1998): 90-I I5; Michel Foucault, Discipline and Punish: The Birth of the Prison (New York: Pantheon Books, 1977), 8; Sebastian Deterding, Dan Dixon, Rilla Khaled, and Lennart Nacke, "From Game Design Elements to Gamefulness: Defining Gamification," in Proceedings of the 15th International Academic MindTrek Conference: Envisioning Future Media Environments (201 I, ACM), 9- 15; Kai Huotari and Juho Hamari, "Defining Gamification: A Service Marketing Perspective," in Proceedings of the I6th International Academic MindTrek Conference (2012, ACM), 17-22.

${ }^{70}$ Goss, "Once-upon-a-Time in the Commodity World," 45; Dastur Francoise, "Phenomenology of the Event: Waiting and Surprise," Hypatia 15 (2000): I78-189.
} 


\section{Acknowledgments}

This research was supported by the Creative Arts Faculty Research Fund of the University of Auckland. I thank my colleagues of the School of Architecture and Planning who provided insight and expertise that greatly assisted the research. I particularly thank my friends and colleagues Franco Manai and Ross Jenner for continuous advice and comments that greatly improved the manuscript, although they may not agree with all of the interpretations of this paper. I want also to acknowledge the invaluable contribution of Jiao Hong, Melanie Milicic, Angelo Bueno and Tanyalak Chalermtip for assistance with the analytical and documental work. I would also like to show my gratitude to the anonymous reviewers for their precious insights. 